\title{
RELIGIÃO E ECONOMIA COMO CULTURAS UNIVERSALISTAS ${ }^{1}$
}

\author{
Joaquim Costa
}

\begin{abstract}
Resumo
A ideia deste artigo persegue-me desde o momento em que, preparando um colóquio, li, num artigo de um economista, que "a economia é uma teologia"; especificava ele, ainda, que Marx, Hayek e Keynes foram "os teólogos mais influentes do século XX". Aos poucos, comparando a expansão dos grandes monoteísmos universalistas com a da moderna economia de mercado, apercebi-me de que o paralelismo entre religião e economia é mais do que um ocioso exercício de analogia. No expansionismo universalista que os alimenta, na linguagem com que invadem e descrevem o mundo, ambas impregnam as nossas vidas e tornam-se a infraestrutura somática das sociedades que conquistaram. Não por acaso, o problema da pobreza e do seu valor teológico tem gerado cismas na Igreja Católica. É coisa atávica e não nos deveria surpreender, pois a pobreza é, a um tempo, economia e teologia.
\end{abstract}

\section{PaLAVRas-chave}

Economia; mercado; pobreza; religião

\begin{abstract}
I have been wrestling with the core idea behind this article ever since, while preparing for a colloquium, I read an article by an economist who claimed that "economics is a theology", and added that Marx, Hayek and Keynes were "the most influential theologians of the twentieth century". By comparing the expansion of the great universalist monotheisms with that of the modern market economy, I slowly realised that the parallelism between religion and economy is more than an idle exercise in analogy. Through the universalistic expansionism that drives them, and the language with which they invade and describe the world, they both permeate our lives and serve as the somatic infrastructure of the societies they have conquered. It is no accident that the problem of poverty and its theological value has generated schisms within the Catholic Church. This is an atavistic question and should come as no surprise, because poverty is related to both economics and theology.
\end{abstract}

\section{KEYWORDS}

Economics; poverty; market, religion

Ser é tudo aquilo que um capitalista gostaria de ter (Afonso Cruz, Enciclopédia da História Universal)

\footnotetext{
' Este artigo é o desenvolvimento de uma comunicação feita no IX Congresso da Associação Portuguesa de Sociologia (Faro, julho de 2016), vertida nas respectivas Actas (Costa, no prelo). Por opção pessoal, escrevo de acordo com as regras anteriores ao Acordo Ortográfico de 1990.
} 
I. Há algum tempo, fui convidado a participar num colóquio sobre religião. Aceitei e, sem saber bem porquê, fui colocado num painel sobre as relações entre o global e o local. Confesso que o primeiro significado que me ocorre com a palavra "globalização" é económico; só depois penso em religião e noutras coisas (cultura, etc.). Daí nasceu este artigo, fruto do embaraço que então senti.

Manuela Silva, economista católica, tem uma perceção oposta à minha. "Num primeiro momento, [a globalização] evoca um desígnio de unidade e comunicação entre todos os povos, abarcando a totalidade do nosso planeta, e lembra expressões como a universalidade do destino humano ou a construção da família humana universal. Neste sentido, merece todo o acolhimento à luz da fé cristã que, na senda de Jesus Cristo, nos abre caminhos de fraternidade e comunhão com toda a criação" (Silva, 2006, p. 28).

Só num segundo momento Manuela Silva fala do significado económico da globalização, vista como "um estádio de evolução da economia": mercado mundial desregulado que apaga fronteiras geográficas, processos de produção e consumo também concebidos à escala mundial, circulação acelerada de recursos materiais e de informação, marketing sem precedentes, peso crescente das transações financeiras em relação àquelas que envolvem bens e serviços (chamadas de "economia real"). Tudo isto, diz ela, transformado pelo "pensamento económico dominante" num paradigma sem alternativas que subestima as suas disfunções e as suas vítimas (Silva, 2006, pp. 29- 30).

Outro economista católico, Américo Mendes, entende a globalização económica de modo semelhante: "alargamento, à escala mundial, do predomínio da economia de mercado" (a qual é, em si mesma, de "natureza expansionista"), com progressivo ascendente da componente financeira sobre a real ${ }^{2}$. Num balanço sobre o expansionismo da relação de mercado e os seus efeitos, recorre a uma imagem religiosa - vislumbra quer o projeto divino do Éden, quer "sombras potencialmente infernais" (Mendes, 2005, pp. 89, 104-105; 2006, pp. 39-45).

Talvez não nos devamos admirar com esta linguagem cruzada entre religião e economia, e possamos vê-la como mais do que um recurso retórico.

Christian Arnsperger, também economista, intitula uma secção de um seu artigo assim: "A economia é uma teologia". Para ele, "o económico é profundamente religioso", não institucionalmente, mas antropologicamente, seja pelo facto de religare as pessoas, seja pela ânsia humana de nos libertarmos da "absurda matéria que nos prende à morte" através da escassez real (e não da imaginária - às vezes opulentamente imaginária - inventada pelo capitalismo). O pensamento económico recebe o impulso do Éden da abundância e aponta à salvação da humanidade: vencer a pobreza, a miséria, a morte. Marx, Hayek e Keynes terão sido, em sentido literal, "os teólogos mais influentes do século XX". Claro que, em se tratando de teologia, não tardaram a pulular heresias e hereges (Arnsperger, 2012, pp. 40-42).

2 Para Américo Mendes, a globalização envolve também a expansão da democracia e dos direitos humanos (2005, pp. 89, 98-99). 
II. Olhando para as duas maiores religiões mundiais, vemo-las como universalistas na natureza e expansionistas na história. O impulso da fraternidade universal de Cristo soltou-se no mapa da Antiguidade animado pelo discurso de inclusão paulino: "não há judeu nem grego; não há escravo nem livre; não há homem e mulher, porque todos vós sois um só em Cristo Jesus" (Gálatas 3, 28).

Ao libertá-los das prescrições judaicas, Paulo tronou possível aos gentios converterem-se ao cristianismo sem, antes, terem de se fazer judeus; com isso, afirma Hans Küng, abriu o caminho para que o credo de uma pequena seita judaica se transformasse numa religião universal a unir Oriente e Ocidente (Küng, 2007, p. 129). Mas a tarefa levou o seu tempo, entretida em múltiplas comunidades, teologias e controvérsias. Constantino, receoso de que a diversidade religiosa dividisse a unidade política, convocou o Concílio de Niceia (325 AD), converteu as decisões conciliares em leis do Império, colou as províncias eclesiásticas às imperiais. Teodósio o Grande (392 AD) fez do Cristianismo religião de Estado e da heresia um crime de Estado. Mais ou menos por essa altura, Prisciliano e seus companheiros foram decapitados - "pela primeira vez, cristãos matam cristãos por divergências na fé. Apesar de vozes de protesto, depressa as pessoas se habituaram a isso" (Küng, 2007, p. 198). O paganismo autóctone foi sumindo da vida pública e o título de sumo sacerdote (Pontifex Maximus), antes imperial, passou para o bispo de Roma. O anti-judaísmo cristianizou-se. A queda do Império não encontrou o vazio (Küng, 2007, p. 198; Vaneigem, 1995, p. 77).

De certa maneira, a cristianização consistiu na expansão da Igreja, a tal ponto que alguns autores a veem como uma corporação global já em séculos recuados ou, talvez melhor, tendo em conta a sua evolução posterior, integrada na formação de impérios coloniais, como uma instituição europeia transplantada para outros continentes (Berger, 2014, pp. 22-23; Furseth \& Repstad, 2006, p. 81).

Pelo caminho, fabricou-se uma identidade cristã (e/ou católica) universal, sob a forma de unidade doutrinária, que deixou muitos escombros heréticos. O edifício, deste ponto de vista, não era muito sólido. Uma religião, escreve Bourdieu, é, de facto, muitas religiões, "sob a capa de um mínimo de dogmas e ritos comuns", enquanto um dogma é vários dogmas, por via das (re)interpretações com que é recebido (Bourdieu, 1987, pp. 51-53). O modelo tem as suas virtualidades e limitações: se, por um lado, transportou a figura una do cristão universal, por outro lado, travou-a. Um dos mais importantes revezes da expansão cristã ocorreu na China, nos princípios do século XVIII, com a proibição, por Clemente XI, de os convertidos chineses incorporarem no cristianismo ritos, espiritualidade e ética da sua cultura: a veneração dos antepassados e de Confúcio, bem como nomes tradicionais dados a Deus ou ao céu, foram banidos da praxis católica local, debaixo da ameaça de excomunhão. A resposta imperial não tardou muito: "expulsão dos missionários, proibição do cristianismo, destruição das igrejas, abjuração forçada da fé cristã", nos dizeres de Hans Küng, que comenta: se, na China, a veneração dos antepassados é a base do laço social, e se a ética confuciana norteia o sistema de valores em geral, então, quem quisesse ser cristão teria de deixar de ser chinês (Küng, 2007, p. 687). Ou seja, ter-se-á anulado o discurso de inclusão paulino. De uma perspetiva mais 
ampla, foi este cristão normativo que guiou a missionação do moderno colonialismo europeu. Aí, a conversão ao cristianismo costumava ser mais do que uma mudança de religião para se tornar numa conversão à cultura europeia, inclusive em assuntos como a arquitetura das missões (Forbes, 1998, pp. 121-122).

Entretanto, dado que o mundo mudou, e muito, a teologia católica abrigou um neologismo nos anos 1970: “inculturação". Não se trata já de traduzir uma teologia eurocêntrica em linguagens locais (teologia da adaptação), senão de ir mais além e aceitar as culturas locais como fonte de inspiração teológica (e pastoral) ou, até, de recriação. Afinal, dizem alguns, nada de novo estaria a ocorrer na história do cristianismo, o qual teria sido o resultado de inculturações várias na sua origem, a começar pela helenização dos primeiros séculos. De qualquer modo, as teologias da inculturação geraram desconfianças mútuas. Pelo lado do Vaticano, receou-se que o processo, deixado em roda livre, desse lugar a simples sincretismos; pelos outros lados (muitos, na Ásia, em África, na América Latina), que a inculturação fosse uma nova estratégia missionária de dominação, o que levou a que se cunhasse outro neologismo: "interculturação", inserta no que parece ser o espírito do diálogo inter-religioso (Teixeira, 2002).

Com mais ou menos querelas interpretativas, a Igreja universal do homo catholicus acabou por receber no seu seio as teologias da inculturação. E fê-lo porque a vida é local, os crentes são locais, as culturas continuam a ter raízes locais. Noutras palavras: a doutrina pode ser extraterritorial, mas as pessoas são territoriais.

Este impulso, digamos, de correção progressista, também transporta em si a tensão oscilatória fundamental de que nasceu. É o mesmo Christian Arnsperger de há pouco quem o diz: nos meios cristãos mais progressistas quer-se o universal como horizonte do cristianismo num mundo pluralista e democrático, embora se tema, com isso, a dissolução da identidade cristã "numa nebulosa laicizada" (Arnsperger, 2012, p. 38).

III. O percurso islâmico na senda do universalismo foi diverso do cristão, logo desde a origem: é que o "fundador do Islão foi o seu próprio Constantino", tendo criado o seu Estado e o embrião do seu Império. Na qualidade de chefe-de-Estado, "governou um lugar e um povo, exerceu a justiça, cobrou impostos, comandou exércitos, declarou a guerra e fez a paz". Não houve regnum separado de sacerdotium (Lewis, 2006, p. 31).

Além disso, a expansão muçulmana não teve paralelo na espantosa rapidez com que foi conquistando território. Em poucas décadas, nas rotas dos exércitos e dos mercadores, tornou irreconhecível o mapa do Mediterrâneo e da Ásia, conquistou civilizações como a egípcia e a persa. Ainda nem um século decorrera após a morte do profeta e um império árabe ia da Índia à Península Ibérica. Parecia que o cristianismo fora atropelado à escala mundial (Küng, 2010, pp. 267-269)3. Nos séculos seguintes, o afã prosseguiu, com avanços e recuos por terras asiáticas e europeias.

\footnotetext{
3 Tal como acontecera com Jesus Cristo, os contributos de Maomé para a História nada tinham de material (conhecimento ou tecnologia). Daí, em parte, as limitações das explicações materialistas para a expansão árabe-islâmica. Na procura de explicação melhor, Bertrand Russel fala em "fanatismo" (1990, p. 97), Hans Küng em "motivação religiosa" (2010, pp. 212213). Creio que ambos querem dizer o mesmo.
} 
Existe um terceiro aspeto peculiar na afirmação do islão como grande religião mundial: o fulgor das primeiras conquistas árabes foi mais expansionista do que universalista. O fito das investidas militares era o da arabização política e não o da islamização religiosa. Por isso, não ocorreram conversões forçadas em massa nos territórios submetidos à nova soberania política. O islão, à época, "era entendido principalmente como religião árabe, uma religião para árabes, e assim deveria continuar" (Küng, 2010, p. 218). Os conquistados, se cristãos ou judeus, são deixados em paz e segregação: devem pagar, por serem dessa condição, um imposto especial aos novos soberanos, o que leva Küng a afirmar que as "conversões não são desejadas; (...) significam perda de receitas de impostos", além de acabarem por conduzir "a exigências de igualdade de privilégios financeiros" (Küng, 2010, p. 218). Raras vezes com acesso a altos cargos civis (não faziam serviço militar), são "cidadãos de segunda classe", em geral com liberdade de religião4. Frequentemente, são maioria ou grande maioria nesses territórios invadidos.

Foi no tempo dos Abássidas, já bem entrado o segundo século da era islâmica, que a arabização cedeu à islamização de carácter universal. A demografia refletiu-se no exército: turcos, corasanos, persas vão adquirindo peso e subindo ao topo da hierarquia militar e administrativa. É a igualdade de todos os crentes que o profeta idealizara. $\mathrm{Na}$ Pérsia, o zoroastrismo quase desaparece; no Magrebe, o cristianismo segue a mesma sorte, mas com nichos significativos. Nos séculos subsequentes, quer no Sudeste asiático, quer na África subsaariana, será este o modelo universalista a prevalecer no islão.

Curioso é que a desarabização político-militar e do estatuto dos crentes não tenha sido acompanhado da correspondente desarabização na identidade religiosa e, até, cultural. O Egipto arabizou-se, o árabe tornou-se a língua franca até dos cristãos do Próximo Oriente (frequentemente, da sua liturgia também) (Küng, 2010, pp. 293-296).

Os convertidos adotam nomes árabes. O grande cisma sunita/xiita é da história árabe relativa à sucessão de Maomé. Para todos, o árabe é a língua do Alcorão. A tradição (suna) é árabe. De certa maneira, reproduziu-se, mutatis mutandis, o caminho cristão: transplantou-se uma instituição árabe para outros cantos do mundo e fabricou-se uma identidade muçulmana universal. Do mesmo modo que no cristianismo, foi preciso, muitas vezes, prensá-la à força. Logo o primeiro califa, Abu Bakr, percebeu que a fé não era suficiente; foi pela tropa que estancou a vaga de apostasia que se seguiu ao falecimento de Maomé em algumas tribos árabes. Da sua estratégia político-militar, faziam parte as pilhagens na Síria, no Iraque e na Pérsia. Foi também nesse tempo ainda primordial que exércitos muçulmanos combateram entre si pela primeira vez. De resto, a violência sectária cedo se manifestou. As várias fações guerreavam-se e isso viu-se no número de califas assassinados, cujos envolvimentos não se resumiam a golpes palacianos, antes chegando a envolver carnificinas. Os secessionistas carijitas, por exemplo, foram massacrados por Ali, que retribuíram assassinando-o no ano de 661 (Küng, 2010, pp. 208, 229, 230). Os politeísmos arábicos foram extintos.

Se no cristianismo o misticismo engendrou desconfianças, assim também no islão. A partir do século VIII, o sufismo adquiriu relevo crescente no mundo muçulmano,

4 Estas condições eram, em princípio, aplicadas a cristãos, judeus e zoroastras. A situação dos "politeístas" era diferente, para pior. A tolerância, para quase todos, desaparecia na Península Arábica, "terra muçulmana" (Küng, 2010, pp. 216-219). 
com um raio de implantação intercontinental. Nos séculos $X$ e seguintes, vários sufis proeminentes foram executados, para exemplo (Küng, 2010, pp. 383-393).

No cerne da identidade universal muçulmana está o Alcorão, ou seja, a própria Palavra de Alá transmitida diretamente em árabe a Maomé, que a terá reproduzido, ipsis verbis, aos escribas. O exame crítico do texto identifica-lhe fontes cristãs e hebraicas, com etimologias várias, ou seja, que é "fruto de um trabalho colectivo" (Costa, 2007, p. 297; Gilliot, 2006). O que espanta não é esta conclusão, trivial em si mesma, mas, sim, a rapidez com que o islão fixou o Alcorão. Como era inevitável, os diversos registos não eram exatamente iguais entre si, o que maculava a perfeição da Revelação e desunia a comunidade dos crentes. Um quarto de século após o falecimento do profeta, estava estabelecido o cânone do Alcorão e, em consequência, atribuído carácter apócrifo às restantes versões, mandadas destruir pelo terceiro califa, Othman, porém ainda a circular furtivas talvez até ao século X. Só com a imprensa foi assegurado o rigor das reproduções (a do Cairo, de 1923, é a definitiva) 5 . No meio de todas as suas dissensões, a canonicidade corânica é indisputada entre os muçulmanos (Alili, 2006; Costa, 2007, pp. 297-298; Gilliot, 2006).

É fascinante ver, na história das grandes religiões, como se alimentam reciprocamente movimentos centrípetos e centrífugos, uniformizadores e diversificadores, repressivos e de resistência. Regressamos à tese de Bourdieu, de que uma religião é muitas religiões, e à ideia de que foi construído um edifício não muito sólido. A relação com a suna divide sunitas e xiitas, as prescrições alimentares acabam por ser territoriais, o jejum também, o Ramadão é adaptado localmente ou eliminado, a oração segue regras diversas (a inculturação não parece ser mera opção). Formaram-se dezenas de minorias dentro do islão, não sendo raro acusarem-se de heréticas umas às outras.

Politicamente, o edifício também tem brechas, sob a fachada do califado e do islamismo. Califas, tivemo-los de 632 a 1924, com estatutos muito vários. Os regimes islamistas sucederam a duas ou três décadas de regimes seculares, se não laicistas, de esquerda e de direita, no Egipto, na Argélia, na Tunísia, na Turquia, no Irão (Costa, 2012). Mesmo a intuição, não descabida de todo, segundo a qual o laicismo é estranho à cultura política muçulmana, merece atenção; para John Gray, pelo menos até há muito pouco tempo a cultura política turca era mais laicista do que a dos Estados Unidos ${ }^{6}$. Se existe uma tradição de regime na Arábia Saudita, existe outra, muito diferente, na Indonésia.

Entretanto, entra-nos violentamente na vida de todos os dias aquele universalismo fundamentalista que quer dissociar-se de qualquer cultura para impor um código de conduta uno, a aplicar na Holanda, no Afeganistão, em toda a parte, na caracterização que Olivier Roy faz dos talibãs afegãos?

\footnotetext{
${ }^{5}$ Deixo de lado a controversa questão dos versículos revogados, bem como a dos versículos satânicos (relativos à $53^{\mathrm{a}}$ surata), que mereceriam, talvez, secção à parte, devido à sua complexidade (que não domino inteiramente).

${ }^{6}$ Vale a pena transcrevermos o trecho: "a religiosidade característica da América está a tornar-se cada vez mais notavelmente acentuada. Possui o movimento fundamentalista que é de longe o mais poderoso de todos os países desenvolvidos. Não há nenhum outro país que de alguma maneira se lhe possa comparar em que os políticos invoquem tão frequentemente o nome de Jesus. Em mais nenhuma parte existem movimentos para banir o darwinismo das escolas públicas. $\mathrm{Na}$ realidade, os Estados Unidos são um regime menos laico do que a Turquia" (Gray, 2004, p. 38).

7 Entrevista ao Público, 2010, 6 de Março.
} 
Tanto Hans Küng como John Gray, nesta matéria, separam o judaísmo do cristianismo e do islamismo. Após o ano de 135 AD, o judaísmo terá abandonado eventuais pretensões universais, além de só muito recentemente ter voltado a poder fazer política e guerra com referente religioso (mas étnico). Pelo contrário, cristianismo e islamismo terão cultivado, praticamente desde a origem, uma "pretensão universal agressiva" (Küng, 2007, p. 356) ou um "universalismo militante" (Gray, 2004, p. 122) depressa caído numa "ideologia de guerra" missionária até à "vitória da própria religião em todo o mundo como objectivo final" (Küng, 2007, p. 356). Salvação universal, para todos; a única e verdadeira.

A tese parece ter algum fundamento ${ }^{8}$. Muitos dos líderes religiosos fundamentalistas islâmicos comportam-se como Olivier Roy os descreve. Ainda que possam parecer anticosmopolitas, fizeram-se atores globais envolvidos em debates globais. Muitas das suas organizações religiosas são multinacionais, o que as leva, mais tarde ou mais cedo, a criar tensões com variados governos nacionais. Contra ou a favor da globalização, as religiões ganham influência pública em toda a parte.

Não soa disparatada a tese de Roland Robertson: o que faz o sistema mundial é menos a economia e mais a cultura - as culturas nacionais com os seus encontros e desencontros, as suas identidades, as suas religiões (Furseth \& Repstad, 2006, pp. 80-81). No meio deste cadinho, tanto irrompem os urros fundamentalistas como as iniciativas inter-religiosas globais e locais.

IV. Assim como a grande religião, a grande economia é universalista e expansionista. Para Américo Mendes, é isso a globalização económica: "o alargamento, à escala mundial, do predomínio da economia de mercado sobre outras formas de organização económica. (...) explica-se este predomínio através da 'natureza expansionista da relação de mercado'" (Mendes, 2006, p. 39). À medida que avança, a conquista deixa marcas no território. A nova economia desmantela muitas economias locais regidas por outras regras, sem lhes dar recursos suficientes para sobreviverem no mercado (Silva, 2006, p. 32). Servida pelo desmantelamento de obstáculos à sua implantação, é impulsionada pelas novas tecnologias da informação, também expansionistas, de modo que estimula a disseminação de conhecimento, o fluxo de capitais, a especialização, a complementaridade de cadeias de produção e distribuição por diversos países, o aumento da produção e do consumo. O desmantelamento não atinge apenas economias pré-industriais - mesmo economias já com experiência industrial, no embate com a grande indústria expansiva propriamente capitalista, sofreram processos de desindustrialização, algumas logo nos séculos XVIII e XIX?.

Não tardou muito até que outro universalismo fundamentalista nos entrasse ostensivamente na vida de todos os dias, para impor um código de conduta uno, a aplicar

\footnotetext{
${ }^{8}$ Com cautela, não vá levar à identificação entre fundamentalismo agressivo e monoteísmo (universalista). Também o hinduísmo tem o seu fundamentalismo violento. Igualmente, com outra natureza, o confucionismo manifesta sinais inquietantes (Küng, 2007, pp. 646-647; a imprensa internacional, uma vez por outra, traz-nos estes sinais).

9 Ver, para o caso da Índia, Clingingsmith e Williamson (2005); os autores, para a desindustrialização indiana, consideram também fatores políticos internos à então possessão britânica.
} 
na Holanda como no Afeganistão: produzir, trocar, consumir, distribuir, redistribuir, sempre do mesmo modo. Se quisermos recorrer ao novo vocabulário invasivo: gerir o mundo sem discriminar nada nem ninguém, a menos que alguém não aceite o código de conduta uno. O código é universalista, sim, mas excludente, não inclusivo, pois é o único e verdadeiro. Igualitário, este universalismo tem vindo a impregnar o ambiente dos nossos melhores negócios, daí se disseminando para os outros, o que é visível nas declarações de missão, nos códigos de boas práticas, etc.: não há homem e mulher, não há judeus e gentios, não há negros e brancos, porque todos os colaboradores e todos os consumidores nos são iguais e a todos servimos por igual. Parece a igualdade cristã invocada por Hannah Arendt: igualdade de almas, indiferente à escravatura durante séculos (1996, p. 143) ${ }^{10}$.

Robert Heilbroner e William Milberg, ambos economistas, parece que descobriram o ovo de Colombo: folheamos revistas inteiras de economia e raramente encontramos uma referência à natureza capitalista (e às classes) das economias estudadas; é como se isso fosse inconcebível, visto que economia existe só aquela. Contudo, se em revistas de História Medieval não se usasse, nunca, a palavra feudalismo, a omissão seria ostensiva. Os economistas modernos têm este tabu, que se tornou no "segredo mais bem guardado da profissão" (o vínculo entre esta economia e capitalismo); tão bem guardado que muitos economistas o desconhecem (Heilbroner \& Milberg, 1998, pp. 20, 145, 146, 149). Os que o conhecem e o nomeiam são colocados no lugar dos recalcitrantes, isto é, ficam sem lugar nos seminários onde se ensina a ciência económica". A própria palavra neoliberalismo é evitada por ser "reducionista" e mal-intencionada; para quê nomear a realidade com outra palavra?

Formou-se uma cultura imperial, "uma cultura que engendra os organismos e as personalidades de que precisa". Tornámo-nos "seres capitalistas", no dizer de Arnsperger, outro economista (2012, p. 58); seres imersos num "senso comum" capitalista que molda o discurso quotidiano, das pessoas ou das instituições, de governantes e governados, invocando a "realidade" da verdadeira natureza humana (Carvalho \& Rodrigues, 2006, p. 344). Alan Wolfe fala de um "ethos de mercado" invasivo, atraente não só na esfera económica, mas também na social e moral. Rodney Dobell vê nisto tudo uma espécie de religião legitimadora dum statu quo que, de outro modo, nos pareceria descaradamente injusto (Haddorf, 2000, pp. 488, 491).

Houve quem interpretasse o fim da cristandade como a derrocada da "religião infraestrutura"; quando a fé cristã deixou de ser a principal "força produtiva" da ordem da economia, entrámos na modernidade secular, cuja superestrutura absorve bem as

\footnotetext{
10 Eis por que este credo, ao contrário de tantos outros, não tem qualquer problema em defender os direitos humanos e a não discriminação: de facto, pouco tem a opor-lhes.

"A nova inquisição vem retratada por Laura Raim em "A polícia do pensamento económico na universidade" (2015). Sucintamente, a universidade, por todo o lado (França, Inglaterra, Estados Unidos, Austrália), desfaz-se de tudo o que é professor e investigador de economia que não seja neoclássico. As disciplinas ou módulos de história do pensamento económico tendem para zero. As revistas económicas mais cotadas rejeitam artigos heterodoxos e chegam a recomendar aos seus autores que tentem publicar em revistas de sociologia (suspeito que, dentro de pouco tempo, nem isso poderão fazer). Da primazia da teologia passou-se à primazia da economia, quero dizer, daquela economia.
} 
religiões da vida privada. A tese não é humorística - de modo nenhum - e, na sua verosimilhança, atualizou-se. Agora, a produção e o controlo da subjetividade como sustentação somática da economia convocam toda a constelação do mercado, da mercadoria ao consumo, sem esquecer nem o crédito nem o desejo. Fredric Jameson vê à sua volta o pior da fetichização da mercadoria, teorizada por Marx: o consumo "tornou-se completamente espiritual", sendo "a materialidade um mero pretexto para o exercício de novos prazeres mentais". A aquisição do bem volatiliza-se depressa, de modo que se pode ir às compras sem comprar nada, fazer shopping sem gastar dinheiro, desde que empenhados na performance certa. O que fica de tudo isto? O Apocalipse como alternativa. Jameson recorda, então, alguém que dissera ser mais fácil imaginar o fim do mundo do que o fim do capitalismo ${ }^{12}$. A fé é assim.

Já noutro lugar expus exemplos recortados da imprensa noticiosa ilustrando que o modelo de mercado atingiu um estatuto transcendente ou, quiçá, metafísico, como fundamento das políticas públicas e das decisões éticas. Segurança rodoviária, consumo de estupefacientes, eutanásia, imigração, aborto, etc., são - e por que não?! - âmbitos cujos enquadramentos político-legais não podem escapar ao crivo inelutável do custo/ benefício económico-financeiro sem disfarce (Costa, 2014).

Dembinski (novamente, um economista) conclui que os mercados são "o único modo de regulação social", o "fundamento do laço social", a "dimensão normativa (...) dos comportamentos" (Dembinski, 2009b, pp. 312-313, 324). Mais: reificaram-se ao ponto de serem fonte e sujeito de Direito, orientarem legislação desreguladora, reclamarem direitos, litigarem por reparação de prejuízos causados por terceiros que desrespeitem os dogmas do livre comércio definidos na Organização Mundial do Comércio (Branco, 2012, pp. 31-32).

A cristandade tinha a sua linguagem. Reconhecemo-la quando visitamos um museu de arte antiga ou quando lemos literatura das mesmas épocas. Impressiona-nos a fixação em motivos sacros e, nos profanos, o recurso a linguagem religiosa que os tornasse persuasivos. Era o que Michel Zink chama "impregnação cristã", uma atmosfera omnipresente que levou os modernos filólogos ao afã de, nos textos medievais, lobrigarem excertos que lhe escapassem. Esta atitude tem o seu quê de anacrónico, pois é muito moderna (Zink, 2003, pp. 1-5).

O ser capitalista também tem a sua linguagem, saturada de impregnação dos mercados, no léxico como nos recursos retóricos. É uma linguagem que descreve um mundo, os seus papéis, a sua legitimação. Toda a gente a conhece: cliente, consumidor, contribuinte, acionista, custo, receita, dívida, credores, empresa, empresário, empreendedorismo, negócio, modelo de negócio, remuneração, crescimento, eficiência, investimento, sucesso, sustentabilidade, escolha, concorrência, inovação, cadeia de valor, mais-valia, mérito, mercado, risco, gestão, marca, qualidade, produto.

As analogias foram atualizadas. As da cristandade caíram na obsolescência. Deixou de se comparar a ordem terrena com a divina, a corte da sociedade com a corte celestial.

\footnotetext{
${ }^{12}$ A ideia da "religião infraestrutura" encontrei-a em Gauchet (1997, p. 236); a da "subjectividade infraestrutura" mercantil, em Lazzarato (2013, p. 49). As reflexões de Jameson sobre a espiritualidade do consumo e o fim do capitalismo, em Jameson, 2010, pp. 195-199.
} 
A tripartição oratores/bellatores/laboratores desfez-se porque todos são (co)laboratores. Milionários exibem o número de horas em que trabalham todos os dias, para exemplo de todos os (co)laboratores. Criou-se um novo elogio fúnebre: "trabalhou até ao último dia com entusiasmo". Quanto menos trabalho existe, mais ele disciplina as mentes, numa renovação do regime de trabalho obrigatório; mesmo que não se possa praticar o trabalho, temos de ser praticantes. Tal como o consumo, o trabalho "tornou-se completamente espiritual", devendo nós ser trabalhadores mesmo sem a materialidade do posto de trabalho desde que nisso empenhados com a performance certa: reproduzir os gestos do trabalho dia após dia, fazer formação profissional sem cessar, entrar e sair de locais de trabalho comprovadamente à procura de trabalho, acorrer a entrevistas individuais que afiancem a nossa fidelidade ao regime laboral (inclusive na nossa intimidade, aberta a perguntas de inspeção). De ordálio em ordálio, o trabalhador praticante talvez receba um óbolo para continuar a peregrinar sem descanso.

Nos atuais arroubos estilísticos, o Estado é uma empresa cujos acionistas são os contribuintes e que está no mercado em concorrência com outras empresas privadas ou públicas, algumas delas sendo outros Estados-empresa. O mercado entra no Estado, o Estado entra no mercado. Hermínio Martins anuncia-nos o nascimento de um verdadeiro mercado de Estados. As grandes empresas já escolhem os Estados onde instalam as suas sedes'3; os Estados concorrem entre si, baixando os impostos para captarem grandes clientes. Os milionários escolhem "no mercado internacional a melhor oferta estatal" para se registarem como contribuintes e, até, como cidadãos (Martins, 2012, pp. 34-35). Estados relapsos, reincidentes na heterodoxia, vêem-se rebaixados ao estatuto de párias, com as respetivas represálias.

Também a universidade se atualizou. Desembaraçou-se das tralhas kantiana (razão) e humboldtiana (cultura) para abraçar a excelência (Readings, 2003). As suas designações foram desertando da antiga hagiografia: institutos, centros, anfiteatros vão adotando nomes de empresas e de empresários; a boa reputação exige que estes integrem os órgãos de governo universitário como conselheiros, curadores, ou como qualquer outra coisa ${ }^{14}$. Cursos, departamentos, etc., sem clientes têm de encerrar; os viáveis têm de fazer benchmarking. O campus deve ser um ninho de empresas. As universidades públicas vão entrando no sector empresarial do Estado (como Fundações ou não - pouco interessa). As entrevistas dos reitores são entrevistas de CEO. Moisés Martins entra em mais detalhes deste processo: diretores de Escola ou Faculdade são "diretores comerciais" empenhados no seu ministério de "mobilização acelerada de professores e alunos para o mercado e para o ranking", submetidos a mecanismos de controlo processual/ tecnológico de garantia da qualidade que não passam de "procedimentos corretivos e ortopédicos" tanto do ensino como da investigação (Martins, 2015, pp. 407-408, 412, 414). Nem os descrentes podem escapar às liturgias e aos responsórios deste credo.

\footnotetext{
13 Frequentemente, são instalações muito pequeninas.

14 Por exemplo, Ricardo Espírito Santo Silva Salgado foi membro do Conselho de Curadores da Universidade de Aveiro, conforme se verifica no Diário da República, $2^{a}$ série, ${ }^{\circ} 199$ de 14 de Outubro de 2009.
} 
O vocabulário espontâneo de todos os dias dá-nos a verosimilhança ontológica em que vivemos: um mercado para tudo, tudo como um mercado. Há mercado financeiro, laboral, religioso, artístico, etc. Há gestão do crédito, dos afetos, do luto, do casamento, etc. O verbo negociar tornou-se muito intrometido.

Certas palavras vão deslizando para outra. Doreen Massey seguiu o lastro de algumas. Pacientes, leitores, estudantes evoluem para cliente. Diz que, assim, em cada deslizamento, uma relação que víamos de uma maneira, com as suas conotações, "é apagada e substituída por uma relação de compra e venda à qual se dá preferência sobre a anterior" (Massey, 2013, p. 3). Diversos papéis são substituídos por um, adequado ao que Jung Mo Sung chama "tratamento de loja" (Sung, 2006, p. 83). Dembinski sustenta que a cupidez foi reabilitada no discurso moral contemporâneo, sob uma máxima: "não há almoços grátis"; misto ambíguo de lei positiva e exortação normativa, alcançou o estatuto de recomendação política (2009b, pp. 328; 2009a, p. 89). Os gestores públicos parecem gostar dela.

Em matéria de educação moral, no Reino Unido há escolas que ensinam às suas crianças muito pequenas as vidas edificantes de empresários de sucesso. Algumas dessas escolas são religiosas e estão "muito em moda (...) mesmo entre famílias irreligiosas". A ideia é tornar o enterprise curriculum obrigatório (Martins, 2012, pp. 20-25). Por cá, já despontou o ensino, em experiências na escolaridade obrigatória, da literacia financeira e do empreendedorismo. Tem prosélitos, porque o analfabetismo é execrável, mas ainda não se sabe quando é que será obrigatório nos currículos para todos. De qualquer maneira, já foi ministrada em mais de 400 escolas públicas no ano de 2015 , a crianças e jovens a partir dos sete anos de idade, promovida pela Junior Achievement Portugal (integrada por Sonae, Grupo Mello, Citibank, entre outros) e, em iniciativa ambiciosa, a bebés entre os quatro e os dezoito meses num instituto lisboeta na versão empreendedorismo para bebés ${ }^{15}$.

E temos uma cosmogonia: "há mercado desde sempre". A cosmogonia não é inteiramente mítica. De facto, desde que há divisão do trabalho e cidades, que se impôs a necessidade de viver em ambiente de trocas comerciais internas e externas. A autossuficiência campesina é uma pré-História da verdadeira vocação humana, revelada no correr do processo civilizacional, avançando na direção certa, mas às vezes com recuos.

No caso do Ocidente, a revolução urbana-mercantil iniciada por volta do século XIV anunciou a moderna civilização burguesa. A autocelebração da nova ordem estigmatizou a era das trevas que a antecedera. A Igreja, à cabeça dessa era, teve, então, como nos recorda Raoul Vaneigem, de se ajustar aos alvores do capitalismo de livre-empresa, incompatível com o conservadorismo da economia agrária; grande latifundiária, "dispendiosa e improdutiva", não servia "a fé do empresário, artesão, banqueiro, industrial", assente em "dinamismo, rendibilidade, parcimónia e espírito inventivo" (Vaneigem, 1995,

\footnotetext{
15 Público, 2015, 7 de abril; Soeiro, 2015. No meu ensino básico, salazarista e marcelista, também havia missionários que visitavam as escolas; lembro-me de um que me comoveu e me fez escrever uma biografia de S. Domingos Sávio e de S. João Bosco, como figuras edificantes.
} 
pp. 106, 137). Ajustou-se como pôde, quero dizer, com lentidão e resistências internas. A Reforma acabou por chegar ${ }^{16}$.

A nova economia de mercado, crescentemente monetarizada, reflete-se nos movimentos religiosos que nela surgem. O seu habitat são as cidades. Mesmo ordens, como as dos franciscanos e dominicanos, no início desconfiadas dos centros urbanos, acabam por ir para lá. A pobreza que cultivam já não é a eremita. Os pobres que querem servir tão-pouco são os então tradicionais: os sem trabalho, os devastados pela guerra, os camponeses fugidos à servidão e caídos na vagabundagem; os novos pobres são gente moderna, que trabalha, artesãos precários sem representação corporativa, operários de construção mal pagos, trabalhadores à jorna. Não tardam medidas para impedir o aumento dos custos salariais (começadas em meados do século XIV - Aragão, Inglaterra, França), para sujeitar os ociosos ao trabalho obrigatório, para proibir hospitalidade aos vagabundos que cresciam de dia para dia a par das sublevações populares. Como as transações tendem para a forma monetarizada, a esmola segue a tendência (Boccadamo, 2014, pp. 233-236; Fiore, 2014, pp. 219, 220).

Os mercadores ganham protagonismo religioso. Uns são elevados aos altares, outros declarados heréticos. Omobomo de Cremona foi o primeiro mercador protomoderno alçado à santidade, nos meados do século XIII. Pela mesma altura, outro mercador, Pedro Valdo, leva à letra o preceito evangélico de Mateus (19, 21: "Vai, vende o que tens, dá o dinheiro aos pobres e terás um tesouro no Céu") e funda o movimento herético dos valdenses, adepto da pobreza voluntária, que alimenta muitas fogueiras por essa Europa fora (Fiore, 2014, pp. 221-222; Vaneigem, 1995, pp. 112-113). Era assim o espírito da época. Francisco de Assis, filho de um mercador rico, revolta-se contra o pai e funda uma ordem de pobreza voluntária, desta vez com a bênção de Inocêncio III; não tarda que os franciscanos vivam um cisma entre moderados (conventuais) e intransigentes (espirituais) na interpretação do que deve ser a pobreza (Fiore, 2014, pp. 221-222; Vaneigem, 1995, p. 113). O século foi cheio de pauperistas radicais e o seguinte igualmente. Houve de tudo: profetas inspirados, bandos armados, chacinas de ricos, albergues para mendigos, doutrinadores (e doutrinadoras), fogueiras de livros e de gentes, autorização eclesiástica da tortura, nascimento da Inquisição. A velha ideia atávica de fixar a Igreja na sua pobreza original encontrava novo estímulo numa ordem socioeconómica que se legitimava combatendo os privilégios da aristocracia, bradando a jacquerie da igualdade. Nesse meio, floresceram as utopias igualitárias, as denúncias do clero em conúbio com os ricos; partiam de gente vária: monges, mercadores, leigos filhos de mercadores, plebeus pobres, pastores de gado, etc.

No ano de 1323, o papa João XXII, pela bula Cum inter Nonnullus, declara herética a proclamação de que Cristo e os apóstolos eram pobres e não possuíam quaisquer bens

\footnotetext{
${ }^{16} \mathrm{Em}$ termos gerais, esta é a tese weberiana, de que Michael Novak discorda, não tanto pelas ideias reformadoras na sua generalidade (que não interpreta exatamente como Weber) mas pelo que ele considera ter sido um enviesamento quanto ao "calvinismo" e ao (não) contributo católico para o capitalismo (Novak, 2001). Num texto inédito até 1940, Marx estabelecera a conexão ascética do capitalismo (Löwy, 1995, p. 43). Mas, no próprio O Capital, já numa nota de pé-de-página aparecia um esboço dessa ideia aludindo à "transformação de quase todos os dias santos tradicionais em dias de trabalho" (Marx, 1990, p. 314).
} 
(Fiore, 2014, p. 222; Sodano, 2014, p. 232). A Igreja adaptava-se ao panteão dos tempos novos. Para Leonardo Boff, era o começo da moderna "divisão no espaço religioso", que oferecia ao mercado a vida pública e à(s) outra(s) religião(ões) a vida privada. "Uma não interfere nem deve interferir na outra" (Boff, 1992, p. 380). De um lado, deve-se evitar a tentação da cobiça; do outro, a tentação do bem. Eis por que tanta gente boa, capaz de se preocupar com o próximo na devoção, é capaz de se comportar como profissional no dever, ou seja, cega a um próximo que não é nem pode ser variável de mercado ${ }^{17}$. No mercado, o bem pode ser o diabo. Peter Drucker escreveu um romance moral em que uma personagem sucumbiu à tentação de fazer o bem na vida profissional. Ajudou os que ficaram para trás, promoveu a ineficiência e, com isso, fez muito mal porque acabou por destruir valor, o que não é coisa que se faça (Sung, 2006, p. 76).

Está aqui, julgo, o cerne da secularização. Dois mundos separam-se, cada um com as suas autoridades e legitimidades, que não se intersectam (e não se disputam). No limite, teríamos a fórmula de Marcel Gauchet - indivíduos religiosos, sociedade ateia (1985, p. 12; 1997, pp. 133, 235-236). Podemos corrigi-la: indivíduos muito religiosos, sociedade agnóstica (segundo aquela religião individual) ${ }^{18}$. Sabemos que a tese clássica da secularização tem sido matizada, mas não deixa de ser curioso observar que as forças religiosas que se opõem firmemente a tal divisão do espaço religioso sejam radicais: cristãos da libertação e islamistas fundamentalistas (Boff, 1992, p. 380).

Sem muita entorse, podemos ver na expansão capitalista o que Hans Küng viu na história do cristianismo e do islamismo: uma "pretensão universal agressiva", um "universalismo militante" até à vitória mundial (Boff, 1992). Recentemente, Jonathan Crary (2014) diagnosticou a saturação dessa conquista total. Vencido o espaço, resta o tempo, paulatinamente em processo de conquista, com o que Crary designa de regime 24/7: o mercado tende a funcionar 24 horas durante 7 dias por semana. O sono representa capacidade ociosa, isto é, inutilização intolerável da capacidade instalada em cada produtor/consumidor. A nova economia dos recursos ociosos visa combater o flagelo da subutilização dos recursos, incluindo os humanos. Kenichi Ohmae, o guru desta evolução, fala de "instalações, equipamentos ou tecnologia" e de "profissionais qualificados", tudo coisas que, em subutilização, podem e devem ser alugadas, porque "a sociedade, como um todo, não ficará satisfeita se tiver de se contentar com a segunda melhor opção, que não otimiza a alocação dos recursos de uma economia". Teve uma epifania: "no momento em que uma empresa nasce, ela deve ter a ambição de servir toda a sociedade. E a sociedade é global. Essa é a beleza do ambiente mobile: há dois sistemas operativos dominantes, iguais em todo o lado. Isso representa um enormíssimo potencial de crescimento". Denunciou as tentações: "a Europa tem de se tornar mais competitiva, não se enredar numa vida confortável. Pensem em férias quando ficarem velhos". Devemos

\footnotetext{
${ }_{17}$ Bichot aplica a este tipo de comportamento o conceito (da Doutrina Social da Igreja) de estrutura de pecado - a cultura financeira e de mercado seria estrutura de pecado (Bichot, 2009, pp. 73-85; Costa, 2014, pp. 54-55).

18 Talvez seja mais fiel falar de agnosticismo (social) em vez de falar de ateísmo. Parece-me que se aplica aqui a ideia que Hannah Arendt fazia do comunismo: é, de raiz, a-religioso, vocacionado para que, no futuro, nem se coloquem questões religiosas (Arendt, 1996, p. 143).
} 
treinar a competição connosco próprios: "se alguém surgir para destruir o nosso modelo de negócio, então que sejamos nós próprios (...) [garantindo] a sobrevivência do negócio sob outras formas"19.

O molde é, como se vê, universal. Na sua génese, é moderno, quero dizer, está, no íntimo, ligado à própria palavra moderno, que é moderna, surgida no século XVI a significar o estado de coisas "do presente", mas pouco depois a significar o futuro, que "seria diferente do passado" e melhor, sempre melhor, no dizer de John Gray. Estava acabada a conceção cíclica da História dos antigos, bem como a medieval, mais dada à ideia de repetição até ao fim do mundo e de salvação no outro mundo (2004, pp. 119, 120). Esse mundo melhor, na filosofia da História que o sustentava, expandir-se-ia ao mundo inteiro. Desde os portugueses e espanhóis dos séculos XVI e XVII até aos americanos desde "há muito", que medrou a ideia de uma modernidade única, igual em toda a parte do mundo, com enorme influência ao acompanhar a expansão do Ocidente (Gray, 2004, pp. 15, 65-66). A noção de um único capitalismo não é original, pois também houve a de um único cristianismo, a de um único socialismo, etc. Segundo Gray, o sucesso do positivismo, que queria fundar uma nova igreja, abriu o caminho ao marxismo e ao neoliberalismo como "cultos pós-cristãos" de ambição universal com um "resíduo de monoteísmo". No fim da História, resume Gray, os positivistas viam o fim da política, eliminadas a escassez e as causas de conflito; haveria "administração racional" das coisas $^{20}$. O mesmo para o comunismo, extintas as classes e o Estado. O mesmo para o neoliberalismo, uma vez triunfante a mão invisível coordenadora das escolhas racionais que vence as paixões da política; é salvação, neste mundo, e sem alternativa - não em latim, não em árabe, senão em inglês.

V. Nas narrativas do(s) Deus(s) misericordioso(s), omnisciente(s) eomnipotente(s), a aporia do mal no mundo arrasta-nos para a questão da teodiceia. Como explicar o sofrimento de inocentes?

$\mathrm{Na}$ narrativa do mercado gerador de riqueza, dotado de omnipresença, a pobreza persistente arrasta-nos para a questão da plutodiceia. Como explicar os círculos viciosos da pobreza, com os seus inocentes (ao menos, os que nela nascem)?

O problema tem os seus espinhos, porquanto não se reduz a uma consequência virtuosa do sistema: na competição económica, os que perdem ficam para trás, caindo na pobreza relativa; e bem poderia ser que os perdedores fossem os últimos no mérito. Contudo, a situação é mais arreliadora.

Se quisermos uma fórmula, ei-la: as novas tecnologias são expansionistas, mas os altos salários não o são - antes pelo contrário. Américo Mendes expõe o mecanismo de dois movimentos inversos: os países subdesenvolvidos aproximam-se dos desenvolvidos na capacidade tecnológica, ao passo que nos custos do trabalho tende a ocorrer o contrário. O círculo virtuoso dos segundos desaparece em nome da competitividade;

\footnotetext{
19 Entrevista de Kenichi Ohmae a Victor Ferreira, Público, 2016, 20 de março.

${ }^{20}$ Ideias dispersas no livro de John Gray (2004), por exemplo, nas páginas 121-124.
} 
então, desloca-se o emprego para economias de baixos salários, baixas contribuições e baixos impostos sobre o capital (desmantelam-se, onde elas existiam, conquistas sociais dadas por adquiridas) (Mendes, 2005, pp. 97-98). Ocorre um desequilíbrio em favor de uma das partes, por, usando uma perspetiva de Bauman, o capital se ter tornado extraterritorial ao passo que as pessoas, apesar de todas as mobilidades, se mantêm territoriais; assim, a acumulação de capital corre para ser independente de qualquer compromisso local com o trabalho (Bauman, 2004, pp. 148-149). Na imprensa quotidiana, aliás, não são raras as notícias de que a compulsão para a redução dos custos do trabalho à escala global origina não baixos salários, mas, sim, muito baixos salários. São as "sombras potencialmente infernais" faladas no início deste texto.

Os alertas contra a pobreza deixam de se centrar apenas nas disparidades internacionais, resvalando para uma linha de disparidades global, alheia a qualquer "nacionalismo metodológico"; a desigualdade de rendimentos não para nas fronteiras e alastra-se pelos países ricos. A riqueza produz tudo em toda a parte, até pobreza.

John Gray enegrece ainda mais o quadro: "os utopistas neoliberais esperavam que a globalização enchesse o mundo de repúblicas liberais, unidas pela paz e pelo comércio. A história está a responder com o florescimento da guerra, da tirania e do império" (Gray, 2004, pp. 131-132). Não parece exagero.

O mercado, se visto como religião terrena, é compelido a desenvolver uma teologia terrena. Salvação, retribuição justa e plutodiceia têm os pés bem assentes na terra. É uma pena, pois, assim, foge-lhe a solução da retribuição extraterrena, muito atraente para o sofrimento imerecido quando na forma de ordem invertida ("os últimos serão os primeiros") ${ }^{21}$.

A solução dos electi traz algum embaraço. Em rigor, trai o universalismo, além de sugerir o mundo extraterreno e de se conotar com outra religião (da vida privada) que repeliria muitos crentes de outras religiões e aqueles que não as têm de todo. Ademais, estabelece a pobreza como uma fatalidade, o que incumpre a promessa de prosperidade generalizada aos empreendedores. Porém, tem o seu conventículo, confirmando as teses weberianas da oposição entre virtuosos e simples fiéis (ou massas) e da necessidade religiosa de os privilegiados legitimarem o seu privilégio. O teólogo Hayek fixou a doutrina: a satisfação do consumo ordinário é "o natural para o simples assalariado", mas não, e de maneira nenhuma, para o grande empreendedor que, na acumulação infinita, vê o meio de "exercitar a sua vocação" (Hayek, 1991, pp. 391-392). Ecoa-nos, dos claustros de Wall Street, o refrão que dá sentido à vida: "ganha aquele que morrer mais rico".

Não saindo do âmbito terreno, existe aquilo que Weber considerava "a solução formalmente mais perfeita do problema da teodiceia" - a doutrina karma que afiança a retribuição das obras passadas, boas ou más, através da transmigração das almas. "O indivíduo cria o seu próprio destino, exclusivamente, no sentido mais rigoroso" (Weber, 1983, p. 416). É, porém, solução muito imperfeita, já que, além de apelar a outra religião, promete retribuição terrena, sim, mas pós-morte. Se usarmos linguagem de

${ }^{21}$ Para uma abordagem sociológica clássica do problema da retribuição e da teodiceia, ver Costa, 2009, pp. 67-69 e Weber, 1983. 
Stark e Bainbridge, o mercado retribui com recompensas (efetivas, tangíveis) e não com compensadores (substitutos intangíveis de recompensas que não existem neste mundo, maxime a promessa de triunfo sobre a morte) (Stark \& Bainbridge, 1980).

De outras tradições religiosas, é possível deitar-se mão à ideia do deus absconditus. Os caminhos do mercado, com a sua mão invisível, seriam insondáveis. A ideia fica como Pilatos no Credo, deslocada num mundo de escolhas racionais desvendadas por uma economia de matemáticos. Friedrich Hayek, o influente teólogo (como lhe chama Arnsperger), deu um passo adiante. Ele, que achava as discussões sobre preço justo e salário justo ociosidades escolásticas, passou da escolástica para a estocástica. O mercado livre maximiza as oportunidades de todos os empreendedores e as probabilidades de o mérito ser recompensado, mas não reduz a zero o estrangulamento de oportunidades nem os casos, talvez aleatórios, de mérito sem o merecido prémio. Quanto melhor funcionar o mercado, menos disfunções destas existirão, as quais derivam de um mecanismo impessoal, não tendo, portanto, nada a ver com justiça ou injustiça (conceitos antropomórficos) (Hayek, 1982, pp. 77-78, 108-110). É uma versão de "precisamos de mais e melhor mercado" a bem da afluência e da cooperação pacífica.

Michael Novak adota tese semelhante: o capitalismo será o sistema que menos pobreza gera e o que mais se apoquenta com ela. Quanto mais e melhor for, menos pobres haverá, e nisto se mostra à saciedade que a pobreza em larga escala não é uma fatalidade. O próprio padrão de riqueza capitalista acaba por ter o efeito perverso de sobreavaliar em muito o número de pobres reais. Grande parte dos falsos pobres parasita as imperfeições do capitalismo, preferindo viver da assistência estatal do que do trabalho honesto; fora esses, restaria uma pequena minoria, incapaz, de facto, de se autossustentar. (Novak, 2001, pp. 215-230). Pobres haverá sempre.

Em falta neste breviário teológico está o que Weber designou de religiosidade de ressentimento, que é de retribuição vingativa (1983, pp. 395-397). Na sua aplicação à religião da vida pública que aqui trato, é sumariamente descartada porque muito dela provém daqueloutro teólogo que foi Karl Marx, rejeitado desde logo por ser materialista.

VI. Nem a divisão do espaço religioso de que fala Leonardo Boff impediu o conflito entre religiões de espaços diferentes; elas evitam-se sempre que podem e querem, mas, como se intersectam de facto, tarde ou cedo entram em litigância.

A bula Cum inter Nonnullus constituiu uma tentativa, na Igreja, de abolir potenciais conflitos entre a religião da vida pública e a da cura privada de almas. Foi um argumento de autoridade, com as suas limitações - os cristãos vivem neste mundo, pelo que acabam por ter de enfrentar as teologias deste mundo. As utopias quiliásticas e igualitárias continuaram a emergir do solo cristão, sob muitas formas. Ânimos mais moderados engendraram ideias ecuménicas de conciliação entre os dois mundos, de modo a que um não paralise o outro, evitando excessos de pauperismos retrogressivos, bom como ressentimentos de guerra civil entre ricos e pobres. Daqui nasceu a moderna Doutrina Social da Igreja, que, desde o começo, teve em mira a reconfiguração do mundo operada pelo capitalismo. A fundadora Rerum Novarum (1891) irrompeu assim, do "gosto 
das coisas novas" e das suas "graves implicações": "a abundância da riqueza nas mãos de um pequeno número e a indigência da multidão" ( $\left.n^{0} 1\right)$. De então para cá, a mesma ferida purulenta continua a alimentar o pensamento social dos sucessores de Leão XIII, vista como "um facto de ordem moral" por João Paulo II (Sollicitudo Rei Socialis, 1987, $\mathrm{n}^{\circ}$ 9), isto é, como um facto "moralmente inaceitável" (Bento XVI, Caritas in Veritate, 2009, $n^{\circ} 32$ ). A acompanhar os tempos, os documentos papais têm vindo a redefinir a natureza da ferida, causada não apenas pela indigência absoluta, mas, em muito, pelas "diferenças de riqueza", pelo "aumento sistemático das desigualdades entre grupos sociais, no interior de um mesmo país e entre populações dos diversos países, ou seja, [pelo] aumento maciço da pobreza, em sentido relativo" (Bento XVI, Caritas in Veritate, $\mathrm{n}^{\circ} 32$ ). O Pontifício Conselho "Justiça e Paz", em Nota de 2011, reforçou o diagnóstico do Papa, em linguagem muito dura para com as ideologias liberais, utilitaristas e tecnocráticas ${ }^{22}$.

$\mathrm{Na}$ mesma encíclica, Bento XVI, o papa conservador, encarou sem rodeios alguns efeitos locais do capital global, para os quais Manuela Silva e Américo Mendes chamavam a atenção. Os Estados encarniçam-se para atraírem investimento estrangeiro, sabendo que só o conseguirão através da redução de custos, ligados ao trabalho e não só: salários, contribuições para a segurança social, impostos sobre os lucros. Daí a denúncia da Caritas in Veritate: ocorre "desregulamentação do mundo do trabalho", com "grave perigo para os direitos dos trabalhadores, os direitos fundamentais da pessoa humana e a solidariedade realizada nas formas tradicionais do Estado Social", extensível às "liberdades sindicais" e à "capacidade negociadora dos próprios sindicatos" (um bem a ser "honrado, hoje ainda mais do que ontem") ( $\left.n^{\circ} 25\right)$.

Tão-pouco foram esquecidos os protagonistas extraterritoriais da nova ordem, nem as suas lealdades: "Nos últimos anos, notou-se o crescimento duma classe cosmopolita de gestores, que muitas vezes respondem só às indicações dos acionistas da empresa, constituídos geralmente por fundos anónimos que estabelecem de facto as suas remunerações" $\left(n^{\circ} 40\right)^{23}$. No n. 21 denunciara os "efeitos deletérios sobre a economia real duma atividade financeira mal utilizada e maioritariamente especulativa" 24.

Talvez por ter sido, além de papa conservador, papa intelectual, é que Ratzinger desmontou a "indústria do consensus" 25 imperante no atual pensamento económico: "o mercado, em estado puro, não existe": é uma construção cultural e ideológica, moralmente não neutra, que pode ser bem ou mal dirigida e que tem as suas disfunções carentes de recta correcção (Caritas in Veritate, $n^{\circ}{ }_{36}$ ).

Provavelmente, ter-se-á inspirado noutro papa conservador que, quase oitenta anos antes, quis restaurar e aperfeiçoar a ordem social "em conformidade com a lei evangélica". Em 1931, Pio XI publicava a encíclica Quadragesimo Anno, preocupado com o rumo

\footnotetext{
${ }^{22}$ Ver Para uma Reforma do Sistema Financeiro e Monetário Internacional na Perspectiva de uma Autoridade Pública de Competência Universal. Retirado de http://www.vatican.va/roman_curia/pontifical_councils/justpeace/documents/rc_pc_justpeace

${ }^{23}$ Inquietação já presente na Quadragesimo Anno, de Pio XI ( $\left.n^{\circ} 105\right)$.

24 Também neste ponto a Quadragesimo Anno revelava preocupações ( $n^{\circ} 106$ e 109).

${ }_{25}$ Expressão usada por Assmann e Hinkelammert (1993, p. 83) para designar o atual pensamento económico dominante e o que ele contém de esquecimento de outros pensamentos económicos.
} 
do mundo (na sequência da crise de 1929). Aí, no n 88, sentenciou: "A prepotência económica, que sucedeu à livre concorrência", é "indómita e violenta por natureza, [e] precisa, para ser útil à humanidade, de ser energicamente refreada, e governada com prudência; ora, não pode refrear-se nem governar-se a si mesma". Também outro papa conservador, além de anticomunista - João Paulo II - já invetivara, na Centesimus Annus, a "idolatria do mercado" (1991, n 40) ${ }^{26}$.

A doutrina, que era clara, tinha-se acelerado nos últimos tempos. Todavia, parecia que não existia, à parte uma ou outra polémica circunstancial ${ }^{27}$. Foi então que um novo Papa a exibiu, gritando "Esta economia mata". De repente, toda a gente deu conta de que se esquecera de alguma coisa. Dir-se-ia, pelas reações havidas, que publicara uma Cum inter Nonnullus ao contrário, quando, em verdade, nestes pontos apenas escancarara a doutrina já fixada pelos seus antecessores. Escancarou-a bem, de facto, na Exortação Apostólica Evangelii Gaudium (2013): o n 202 proclama que "a desigualdade é a raiz dos males sociais", enquanto no seguinte a anáfora não esconde a intenção de repetir até à exaustão uma ideia -

incomoda que se fale de ética, incomoda que se fale de solidariedade mundial, incomoda que se fale de distribuição dos bens, incomoda que se fale de defender os postos de trabalho, incomoda que se fale da dignidade dos fracos, incomoda que se fale de um Deus que exige um compromisso em prol da justiça.

O papa Francisco incomodou a sério porque o fez com a Doutrina Social da Igreja e não com a "teologia". Destarte, interferiu sem diplomacia nenhuma na tutela de outra religião, que respondeu com ímpetos de guerra religiosa pouco ou nada diplomáticos - o Papa é um ignorante em economia, desconhece as virtudes da desigualdade distributiva e da competição, abraça a utopia de um comunismo cristão presente no continente de onde veio sob a forma de teologia da libertação, esquece-se de que o samaritano foi misericordioso porque era rico. Corolário: Francisco "só tem a oferecer aos pobres compaixão e esmola" ${ }^{28}$. Esta última reprimenda é curiosa porque um sistema de esmola generalizada, que substitua as quermesses de caridade pelas campanhas de solidariedade, é tudo o que o Papa não quer. E, nisto, segue a Caritas in Veritate de um Bento XVI que não foi acusado de ignorante: a justiça distributiva deve reger o mercado ( $\left.n^{\circ} 35\right)$, e "os cânones da justiça devem ser respeitados desde o início, enquanto se desenrola o processo económico [globalizado], e não depois ou marginalmente" ( $\left.n^{\circ} 37\right)$. Sem tais escrúpulos, cair-se-á "no assistencialismo que humilha o sujeito necessitado" ( $\left.n^{\circ}{ }_{58}\right)$.

$\mathrm{Na}$ homilia de Ano Novo de 2015, Francisco condenou todas as formas de escravatura moderna. No mês anterior, tinha-se dirigido aos consumidores, quase sempre esquecidos na avaliação moral da cadeia económica; pediu-lhes que não comprassem

\footnotetext{
${ }^{26}$ Para exposição um pouco mais desenvolvida destes aspetos da Doutrina Social da Igreja ver Costa (2014).

${ }^{27}$ Por exemplo, aquando da saída da Caritas in Veritate.

${ }^{28}$ Ver Hengsbach (2014), que faz um bom apanhado destas reações à Exortação Apostólica.
} 
produtos de baixo preço assentes em trabalho de muito baixo custo, próximo da servidão ou da escravatura, imerso na imensa teia de produção, troca e consumo da globalização (Público, 2015, 2 de janeiro). Será uma "escravatura" moderna, com negreiros globais e capatazes locais.

Estava traçada, irreversivelmente, a reputação de Papa. É ela que faz as suas mensagens. Em meados de 2015, publicou a Encíclica Laudato Si, depressa vista como a encíclica ecológica. Retomou ensinamentos de diversos antecessores, mas a reputação do próprio sobrepôs-se-lhes em absoluto, pelo que ganhou novo fôlego o velho conceito de destino universal dos bens, a começar pela Terra como casa de todos, à qual não se devem sobrepor os interesses dos grandes grupos económicos nem relações de propriedade perversas.

O título da encíclica é uma pobreza franciscana. Conventual ou espiritual?

\section{REFERÊNCIAS BIBLIOGRÁFICAS}

Alili, R. (2006). La naissance du livre. Le Monde des Religions, 19, 26-29.

Arendt, H. (1996). Religion et politique. In H. Arendt, La Nature du Totalitarisme (pp. 139-168). Paris: Payot.

Arnsperger, C. (2012). De l'homme réel à l'homme possible en économie - Une transgression chrétienne de l'identité capitaliste?. In B. Bourgine, J. Famerée \& P. Scolas (Eds.), La Transgression Chrétienne des Identités (pp. 37-59). Paris/Lovaina: CERF/U.C.Lovaina.

Assamann, H. \& Hinkelammert, F. J. (1993). L'idôlatrie du marché - Critique théologique de l'économie de marché. Paris: CERF.

Bauman, Z. (2004). Liquid modernity. Cambridge: Polity Press.

Bento XVI (2009). Caritas in Veritas. Retirado de http://w2.vatican.va/content/benedict-xvi/pt/encyclicals/ documents/hf_ben-xvi_enc_20090629_caritas-in-veritate.html

Berger, P. (2014). The many altars of modernity - Toward a paradigm for religion in a pluralist age. Boston/Berlin: De Gruyter.

Bichot, J. (2009). Sollicitudo rei socialis: Finance et structures de péché. In Paul H. Dembinsky (Ed.), Pratiques Financières, Regards Chrétiens (pp. 59-87). Paris: Desclée de Brouwer.

Boccadamo, G. (2014). Os pobres, os peregrinos e a assistência. In U. Eco (Ed.), Idade Média, Castelos, Mercadores e Poetas) (vol. III, pp. 232-236). Alfragide: Dom Quixote.

Boff, L. (1992). El mercado y la religión del mercantilismo. Concilium (Espanha), 241 (El Fundamentalismo en las Grandes religiones), 375-381.

Bourdieu, P. (1987). Gênese e estrutura do campo religioso. In P. Bourdieu, A Economia das Trocas Simbólicas (pp. 27-78). São Paulo: Editora Perspectiva.

Branco, M. C. (2012). Economics against democracy. Review of Radical Political Economics, 44(1), 23-39.

Carvalho, L. F. \& Rodrigues, J. (2006). On markets and morality: Revisiting Fred Hirsch. Review of Social Economy, LXIV(3), 331-348. 
Clingingsmith, D. \& Williamson, J. G. (2005). India's deindustrialization in the 18th and 19th centuries. Retirado de http://citeseerx.ist.psu.edu/viewdoc/download?doi=10.1.1.500.7037\&rep=rep1\&type=pdf

Costa, J. (2007). Sentido da vida, desespero e transcendência. Revista Lusófona da Ciência das Religiões, VI(12), 287-308. Retirado de http://recil.ulusofona.pt/bitstream/handle/10437/4179/sentido_da_vida_ desespero_e_transcendencia.pdf?sequence $=1$

Costa, J. (2012). Fé e narrativas de progresso. Revista Lusófona da Ciência das Religiões, XI(16/17), 331-339.

Costa, J. (2014). O que é uma universidade católica? Estudo sociológico sobre o ensino de economia e gestão na Universidade Católica Portuguesa. Braga: Centro de Estudos De Comunicação e Sociedade. Retirado de http://repositorium.sdum.uminho.pt/handle/1822/36847

Costa, J. (no prelo). Religião e economia: globalização e extraterritorialidade. Actas do IX Congresso da Associação Portuguesa de Sociologia, Faro.

Crary, J. (2014). 24/7 - Late capitalisme and the ends of sleep. Londres/Nova lorque: Verso.

Dembinski, P. H. (2009a). Caritas in veritate: De l'incomplétude de la pensée et da la pratique économique. In Paul H. Dembinsky (Ed.), Pratiques Financières, Regards Chrétiens (pp. 89-93). Paris: Desclée de Brouwer.

Dembinsky, P. H. (2009b). La financiarisation: un enjeu de civilisation. In P. H. Dembinsky (Ed.), Pratiques Financières, Regards Chrétiens (pp. 311-331). Paris: Desclée de Brouwer.

Ferreira, V. (2016, 20 de março). O ano de 2015 marca o big bang da economia ociosa. Público, pp. 32-33.

Fiore, C. de (2014). Aspirações de renovação religiosa da igreja e heresias. In U. Eco (Ed.), Idade Média. Castelos, Mercadores e Poetas) (vol. III, pp. 219-228). Alfragide: Dom Quixote.

Forbes, J. D. (1998). Colombo e outros canibais. Lisboa: Edições Antígona.

Francisco (2013). Evangelii Gaudium. Retirado de https://w2.vatican.va/content/francesco/pt/apost_ exhortations/documents/papa-francesco_esortazione-ap_20131124_evangelii-gaudium.html

Francisco (2015). Laudato Si. Retirado de http://w2.vatican.va/content/francesco/pt/encyclicals/documents/ papa-francesco_20150524_enciclica-laudato-si.html

Furseth, I. \& Repstad, P. (2006). An introduction to the sociology of religion - Classical and contemporary perspectives. Aldershot (Reino Unido)/Barlington (EUA): Ashgate.

Gauchet, M. (1985). La religion de la sortie de la religion. Autrement, 75, 12-17.

Gauchet, M. (1997). Le désenchantement du monde - Une histoire politique de la religion. Paris: Gallimard.

Gilliot, C. (2006). Les sources du coran. Le monde des religions, 19, 30-33.

Gray, J. (2004). Al-Q̨aeda e o significado de ser moderno. Lisboa: Relógio D’Água.

Haddorf, D. W. (2000). Religion and the market: Opposition, absorption or ambiguity?. Review of Social Economy, LVIII(4), 483-504.

Hayek, F. A. (1982). Droit, législation et liberté - 2 - Le Mirage da la justice sociale. Paris: P.U.F.

Hayek, F. A. (1991). Los fundamentos de la libertad. Madrid: Unión Editorial.

Heilbroner, R. \& Milberg, W. (1998). La crisis de cisión en el pensamiento económico moderno. Barcelona/ Buenos Aires: Ediciones Paidós Ibérica. 
Hengsbach, F. (2014). El Papa se equivoca - el Papa tiene razón. Selecciones de Teologia, 53(212), 253-260. Retirado de http://www.seleccionesdeteologia.net/selecciones/lib/vol53/212/212_Hengsbach.pdf

Jameson, F. (2010). A cidade do futuro. Libertas, 10(1), 181-200.

João Paulo II (1987). Sollicitudo Rei Socialis. Retirado de http://w2.vatican.va/content/john-paul-ii/pt/ encyclicals/documents/hf_jp-ii_enc_30121987_sollicitudo-rei-socialis.html

João Paulo II (1991). Centesimus Annus. Retirado de http://w2.vatican.va/content/john-paul-ii/pt/encyclicals/ documents/hf_jp-ii_enc_01051991_centesimus-annus.html

Küng, H. (2007). El cristianismo - Esencia e historia. Madrid: Editorial Trotta.

Küng, H. (2010). Islão - Passado, presente e futuro. Lisboa: Edições 70.

Lazzarato, M. (2013). La fábrica del hombre endeudado - Ensayo sobre la condición neoliberal. Buenos Aires: Amorrortu.

Lewis, B. (2006). A crise do islão - Guerra santa e terror ímpio. Lisboa: Relógio D’Água.

Lopes, M. S. (2010, 6 de março). Islão. A nova jihad trava-se Público (Caderno P2), pp. 10-13.

Löwy, M. (1995). Karl Marx et Friedrich Engels comme sociologues des religions. Archives des Sciences Sociales des Religions, 89, 41-52.

Martelo, R. M. (2013). Questões de vocabulário. Cão Celeste, 4, 5-13.

Martins, H. (2012). Empresas, mercados, tecnologia - Uma perspectiva biográfica. Nada, 16, 16-39.

Martins, M. de L. (2015). A liberdade académica e os seus inimigos. Comunicação e Sociedade, 27, 405-420. Retirado de http://revistacomsoc.pt/index.php/comsoc/article/view/2109

Marx, K. (1990). O capital (Livro Primeiro, Tomo I). Lisboa/Moscovo: Edições «Avante!»/Edições Progresso.

Massey, D. (2013). Vocabularies of the economy. Retirado de https://www.lwbooks.co.uk/sites/default/ files/or_vocabularieseconomy.pdf

Mendes, A. (2005). Luzes e sombras da globalização. Theologica, 40(1), 89-106.

Mendes, A. (2006). Globalização financeira. Communio, XXIII(2006/1), 39-53.

Novak, M. (2001). A ética católica e o espírito do capitalismo. Cascais: Principia.

Pio XI (1931). Quadragesimo Anno. Retirado de https://w2.vatican.va/content/pius-xi/pt/encyclicals/ documents/hf_p-xi_enc_19310515_quadragesimo-anno.html

Público, (2015, 2 janeiro). Papa pede luta contra a "escravatura moderna". Público, p. 21.

Público (2015, 7 de abril). Literatura financeira. O minucioso trabalho da formiguinha. Público, pp. 12-13.

Raim, L. (2015). A polícia do pensamento económico na universidade. Le Monde Diplomatique (edição portuguesa).

Readings, B. (2003). A universidade em ruínas. Coimbra: Angelus Novus.

Russel, B. (1990). O poder - Uma nova análise social. Lisboa: Editorial Fragmentos. 
Silva, M. (2006). Para além da miragem dos sucessos da globalização. Communio, XXIII(2006/1), 27-38.

Sodano, G. (2014). A inquisição episcopal e a inquisição pontifícia. In U. Eco (Ed.), Idade Média. Castelos, Mercadores e Poetas (vol. III, pp. 229-232). Alfragide: Dom Quixote.

Soeiro, J. (2015. 8 de maio). A mocidade empreendedora ou o professor karamba vai à escola. [Blogue] Expresso Blogues. Retirado de http://expresso.sapo.pt/ blogues/2015-05-08-A-Mocidade-Empreendedora-ou-o-Professor-Karamba-vai-a-escola

Stark, R. \& Bainbridge, W. S. (1980). Towards a theory of religion: religious commitment. Journal for the Scientific Study of Religion, 19(2),114-128.

Sung, J. M. (2006). Educar para reencantar a vida. Petrópolis: Vozes.

Teixeira, F. (2001). Inculturação da fé e pluralismo religioso. In S. Tavares(Ed.), Inculturação da fé (pp. 82-99). Petrópolis: Vozes.

Vaneigem, R. (1995). As heresias. Lisboa: Edições Antígona.

Weber, M. (1983). Economia y sociedad. México: Fondo de Cultura Económica.

Zink, M. (2003). Poésie et conversion au Moyen Âge. Paris: PUF.

\section{NotA BIOGRÁFICA}

Doutorado em sociologia, Professor Auxiliar do Departamento de Sociologia da Universidade do Minho, e membro do Centro de Estudos de Comunicação e Sociedade (CECS) da mesma universidade.

E-mail: ajbfjc@ics.uminho.pt

Departamento de Sociologia

Centro de Estudos de Comunicação e Sociedade, Instituto de Ciências Sociais, Campus de Gualtar, 4710-057 Braga, Portugal

\section{Submetido: 10/03/2017 \\ Aceite: 05/05/2017}

